\title{
Downregulation of Polyamine and Diamine Oxidases in Silicon-Treated Cucumber
}

\author{
Anita Szegő ${ }^{1,+}$, Iman Mirmazloum ${ }^{1, *,+} \mathbb{D}$, Zsolt Pónya ${ }^{2}$, Oyuntogtokh Bat-Erdene ${ }^{1}$, Mohammad Omran ${ }^{1} \mathbb{D}$, \\ Erzsébet Kiss-Bába ${ }^{1}$, Márta Gyöngyik ${ }^{1}$ and István Papp ${ }^{1}$
}

1 Department of Plant Physiology and Plant Ecology, Institute of Agronomy, Hungarian University of Agriculture and Life Sciences, Ménesi Str. 44, 1118 Budapest, Hungary; Szego.Anita@uni-mate.hu (A.S.); oyuntogtokhb@gmail.com (O.B.-E.); mohammad.omran1994@gmail.com (M.O.); Kissne.Baba.Erzsebet.Ilona@uni-mate.hu (E.K.-B.); Gyongyik.marta@gmail.com (M.G.); papp.istvan@uni-mate.hu (I.P.)

2 Division of Applied Food Crop Production, Department of Agronomy, Institute of Agronomy, Kaposvár Campus, Hungarian University of Agricultural and Life Sciences, Guba Sándor Str. 40, 7400 Kaposvár, Hungary; ponyazs@yahoo.com

* Correspondence: mirmazloum.seyediman@uni-mate.hu

+ Anita Szegő and Iman Mirmazloum contributed to this work equally as co-first authors.

Citation: Szegő, A.; Mirmazloum, I.; Pónya, Z.; Bat-Erdene, O.; Omran, M.; Kiss-Bába, E.; Gyöngyik, M.; Papp, I. Downregulation of Polyamine and Diamine Oxidases in Silicon-Treated Cucumber. Plants 2021, 10, 1248. https://doi.org/10.3390/ plants10061248

Academic Editor: Alessandra Cona

Received: 13 May 2021

Accepted: 17 June 2021

Published: 19 June 2021

Publisher's Note: MDPI stays neutral with regard to jurisdictional claims in published maps and institutional affiliations.

Copyright: (c) 2021 by the authors. Licensee MDPI, Basel, Switzerland. This article is an open access article distributed under the terms and conditions of the Creative Commons Attribution (CC BY) license (https:/ / creativecommons.org/licenses/by/ $4.0 /)$.

\begin{abstract}
Silicon (Si) is a ubiquitous element in soil with well-known beneficial effects under certain conditions, in several plant species, if supplied in available form for uptake. It may alleviate damage in various stress situations and may also promote growth when no obvious stressors are applied. Effects of Si are often linked to mitigation of oxidative stress, in particular to the induction of antioxidant defense mechanisms. In the work presented, the impact of silicon provision on prooxidant systems was investigated in cucumber. Plants of the F1 cultivar hybrid 'Joker' were grown under in vitro conditions in the absence of any applied external stressor. Silicon provision decreased $\mathrm{H}_{2} \mathrm{O}_{2}$ content and lowered lipid peroxidation in the leaves of the treated plants. This was paralleled by declining polyamine oxidase (PAO) and diamine oxidase (DAO) activities. Several PAO as well as lipoxygenase (LOX) genes were coordinately downregulated in Si-treated plants. Unlike in similar systems studied earlier, the Si effect was not associated with an increased transcript level of gene coding for antioxidant enzymes. These results suggest an inhibitory effect of Si provision on prooxidant amine oxidases, which may decrease the level of reactive oxygen species by retarding their production. This extends the molecular mechanisms linked to silicon effects onto redox balance in plants.
\end{abstract}

Keywords: polyamine oxidase; diamine oxidase; reactive oxygen species; silicate; Cucumis sativus

\section{Introduction}

Silicon (Si) is an abundant element in the earth's crust, which may be necessary and can have beneficial effects in several plant species in varying degrees [1,2]. Grasses typically display high silicon level, while cucumber is a moderate Si accumulator [3]. Si may alleviate damage under stress conditions, but it can also improve growth in apparently stress-free situations $[4,5]$. In plants, silicon interacts with various cell wall components through biosilicification [6]. This results in direct effects such as mechanical strengthening, but indirect physiological consequences are also becoming evident. In biotic interactions, for example, Si nutrition triggered the elevated resistance of miniature roses towards the fungus Podosphaera pannosa. This effect was attributed to the accumulation of antifungal phenolic compounds [7]. As a concept for providing a general explanation of the diverse physiological effects of silicon, the 'apoplastic obstruction hypothesis' has recently been put forward [8]. According to this model, Si may serve as an extracellular 'prophylactic agent', inhibiting cell wall related reactions/interactions. Observed effects of Si provision may ultimately be due to these apoplastic interferences with diverse downstream consequences 
through cascading molecular events. Beneficial effects of silicon treatment have frequently been studied in relation to abiotic stresses. In a well-characterized example, the salt stress tolerance of cucumber was improved by $\mathrm{Si}$ treatment, which was ascribed to increased antioxidant enzyme activities and polyamine accumulation $[9,10]$. Polyamine metabolism is active in the extracellular space; in particular, amine oxidases contribute to production of reactive oxygen species in this compartment [11,12]. Besides a traditional role in wound response, lipoxygenases may also contribute to shaping the redox balance in diverse abiotic stress conditions [13]. In the work presented here, we set out to investigate whether the regulation of amine oxidases and lipoxygenases may display any characteristic patterns corresponding to redox balance in response to $\mathrm{Si}$ treatment in cucumber.

\section{Results}

\subsection{Plant Growth and Silicate Content}

Silicate treated plants did not display any major phenotypic alterations when compared to controls during the experimental period (Figure 1A). Growth of treated plants was not significantly different by the end of the experiment (Figure 1B). The Si concentration increased significantly in treated plants. Leaves of plants with Si-supplemented fertigation accumulated $254.69 \mathrm{mg} \cdot \mathrm{g}^{-1} \mathrm{DW}$ of silicon, whereas the concentration of Si in control plants was 146.05 mg.g ${ }^{-1}$ DW (Figure 1C).

\subsection{Bio-Photon Emission Imaging}

Plants displayed moderate levels of spontaneous bio-photon emission under the growth conditions applied, in the absence of any particular stress treatment. Quantification approved substantially and significantly $(p<0.05)$ lower levels of bio-photon emission from the leaves of plants treated with silicon (Figure 2).

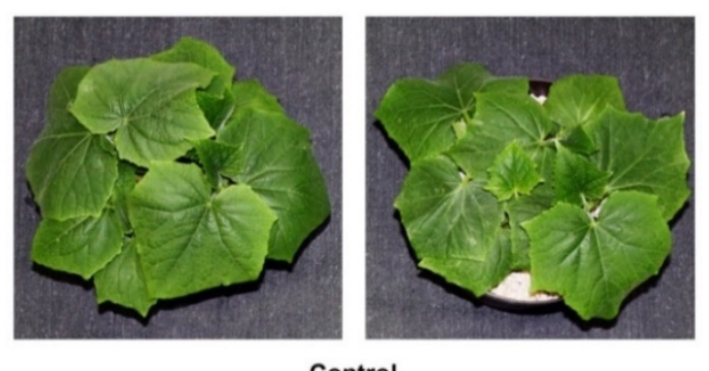

Control

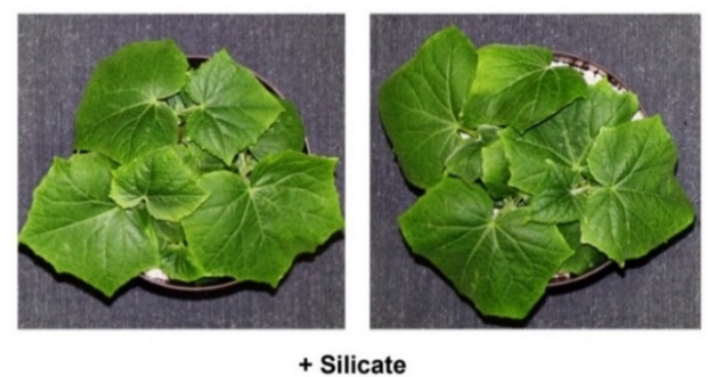

(A)

Figure 1. Cont. 


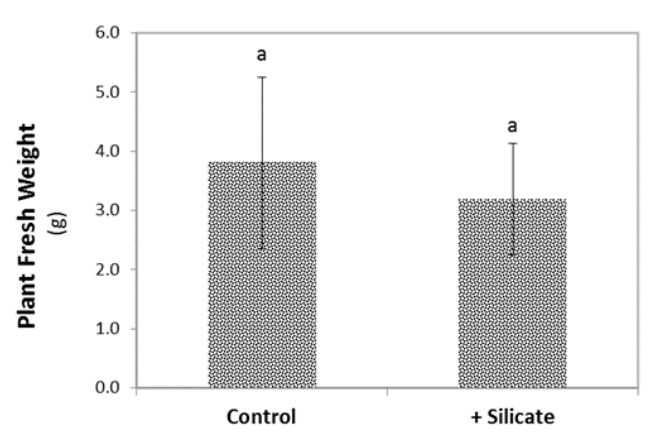

(B)

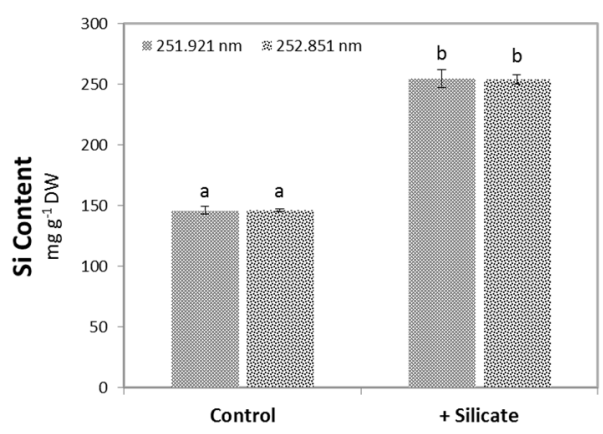

(C)

Figure 1. (A): 'Joker' plants grown in vitro without (upper panel) and with (lower panel) silicate-supplemented fertigation; (B): Fresh weight; and (C): silicon content of the plants at the end of the experiment. Values are means \pm SD and different letters above the bars indicate significant difference between the treatments (Tukey post hoc: $p<0.05$ ); $n=20$.
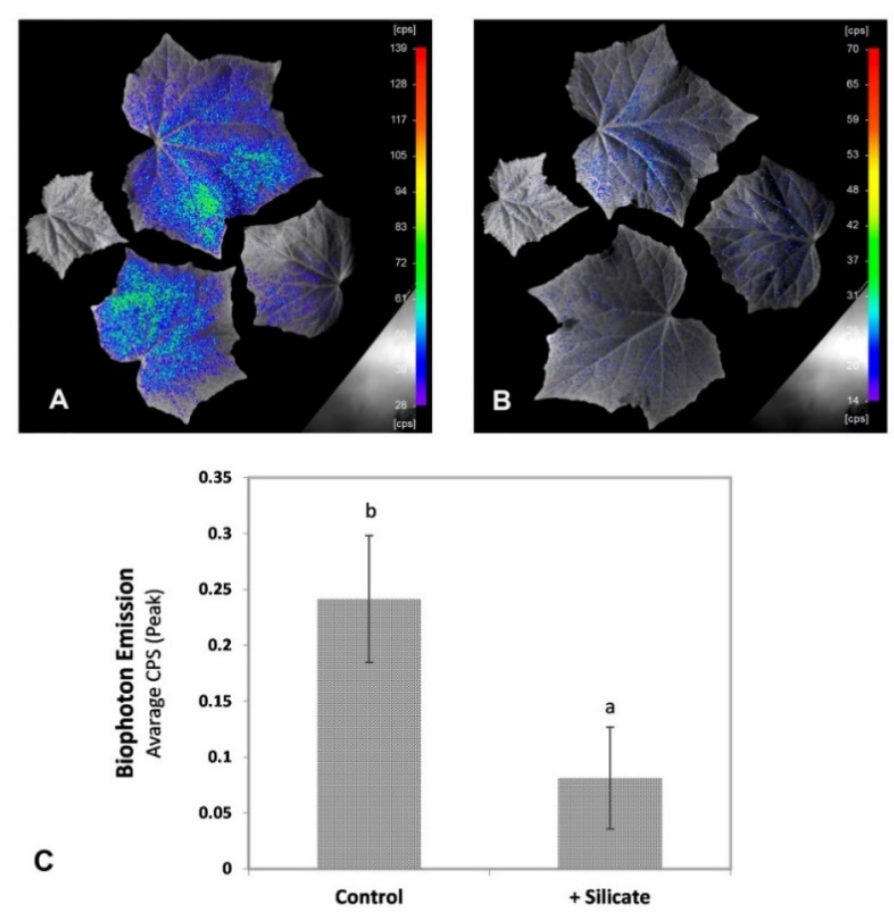

Figure 2. False colored images based on bioluminescence of typical (A): control and (B): silicatetreated plants. (C): Results of bio-photon emission (average count per second) in control and silicate-treated cucumber leaves. Bio-photon emission decreased significantly in response to Si treatment. Values are means $\pm \mathrm{SD}$ and different letters above the bars indicate significant difference between the treatments (Tukey post hoc: $p<0.05$ ); $n \geq 50$.

\section{3. $\mathrm{H}_{2} \mathrm{O}_{2}$ Content and Lipid Peroxidation}

Control plants displayed moderate coloration by DAB staining under the growth conditions applied. This staining disappeared along with a significant decline $(p<0.05)$ of $\mathrm{H}_{2} \mathrm{O}_{2}$ content (from $1.624 \mu \mathrm{M}$ to $1.353 \mu \mathrm{M}$ per gram fresh weight) when cucumber plants were treated with silicon (Figure $3 \mathrm{~A}-\mathrm{C}$ ). The lipid peroxide content of the leaves also decreased significantly $(p<0.05)$, from 1.227 to $0.704 \mu \mathrm{M} \cdot \mathrm{g}^{-1} \mathrm{FW}$, due to the Si treatment (Figure 3D).

\subsection{Polyamine Oxidase, Diamine Oxidase, and Ascorbate Peroxidase Enzyme Activities}

As presented in Figure $4 \mathrm{~A}, \mathrm{~B}$, the polyamine oxidase (PAO) and diamine oxidase (DAO) enzyme activities in cucumber leaves declined significantly $(p<0.05)$ as a result 
of Si-supplemented fertigation, while the ascorbate peroxidase (APX) activity remained unchanged (Figure 4C).

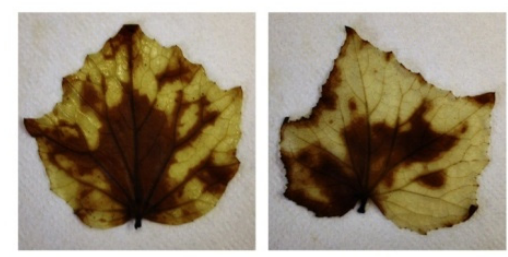

A

Control

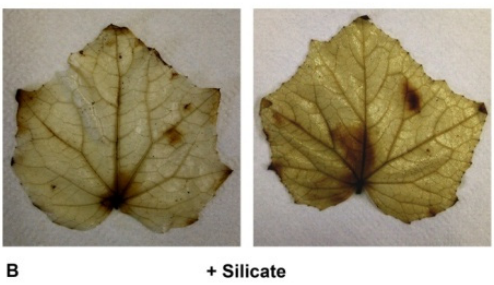

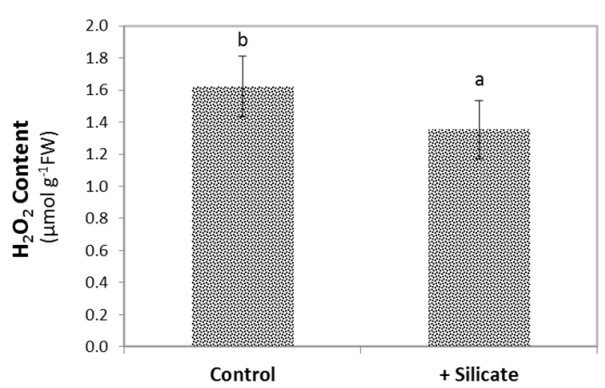

(C)

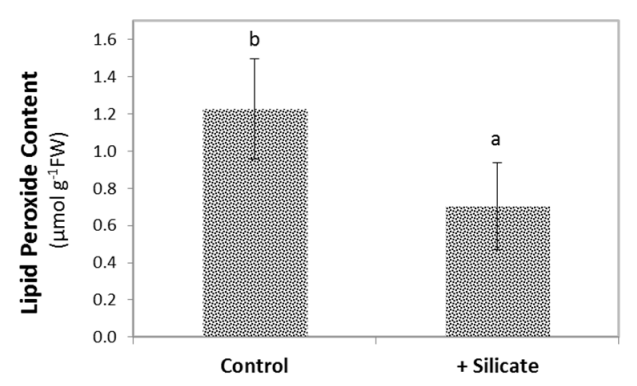

(D)

Figure 3. DAB staining of cucumber leaves of (A): control and (B): silicate-treated plants. $(\mathbf{C}): \mathrm{H}_{2} \mathrm{O}_{2}$ and (D): lipid peroxide content of control and Si-treated plants. Values are means \pm SD and different letters above the bars indicate significant difference between the treatments (Tukey post hoc: $p<0.05$ ); $n=8$.

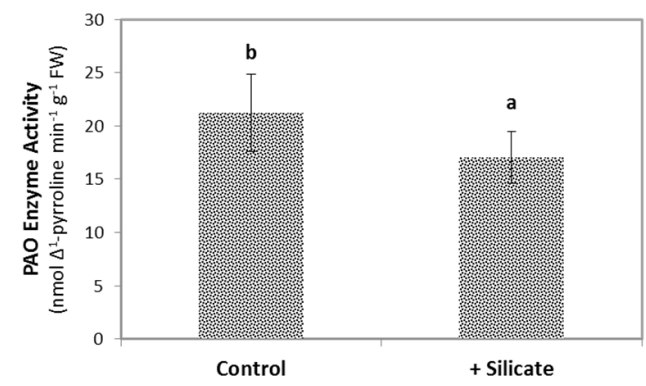

(A)

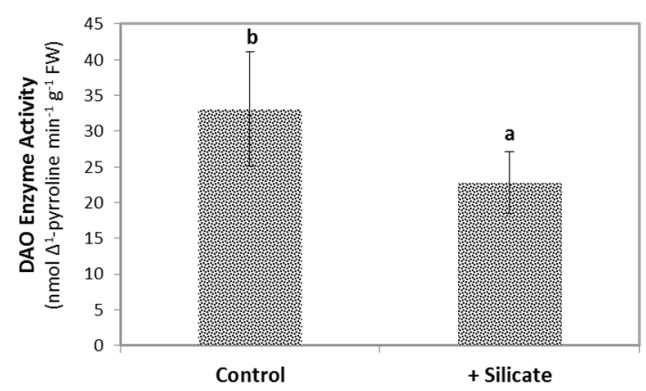

(B)

Figure 4. Cont. 


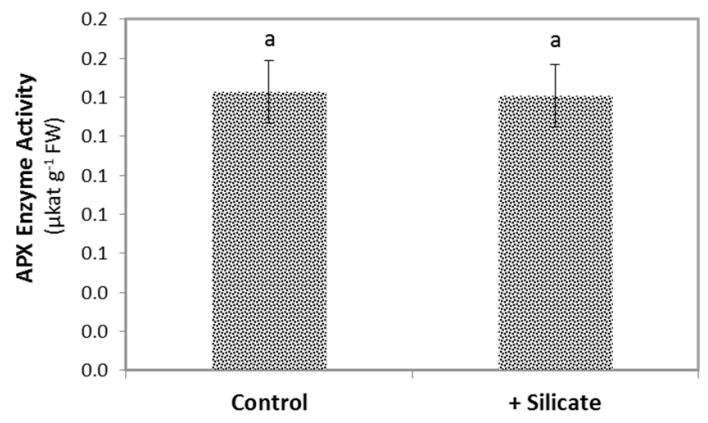

(C)

Figure 4. (A): PAO (Polyamine Oxidase); (B): DAO (Diamine Oxidase); and (C): APX (Ascorbate Peroxidase) enzyme activities in leaves of control and Si-treated cucumber plants. Values are means \pm SD and different letters above the bars indicate significant difference between the treatments (Tukey post hoc: $p<0.05) ; n=8$.

\subsection{Transcriptional Analysis of Selected Redox-Related Genes}

Based on published data and the cucumber genomic sequence, several selected genes have been implicated or presumed to function in redox protection in cucumber. The ascorbate peroxidase genes (APX1 and APX2) were taken from the cucurbit genomic database (http: / / cucurbitgenomics.org/, accessed on 1 October 2020) by keyword search for coding mRNA sequences and were selected based on the gene expression data of deposited bio projects. The glutathione peroxidase (GPX1) was selected from the work of Zhou et al. [14] due to its exceptionally high responsiveness and its expression recorded on $\mathrm{NaCl}$ and PEG treatment in their study. Two glutathione reductase (GR1 and GR2) and four polyamine oxidase genes were found for cucumber after mining the cucurbit genome data base. The lipoxygenase genes were selected based on their reported expression in cucumber leaves by Yang et al. [15].

The expression of the selected APX, GPX, GR, PAO, and LOX genes was tested by semi-quantitative RT-PCRs. All reactions were performed on the same amount of cDNA, and yielded products of the expected fragment sizes (Table S1).

According to the semi-quantitative RT-PCR data presented in Figure 5, all selected genes were found to be downregulated in response to silicate treatment as compared to the control actin gene (Figure 5).
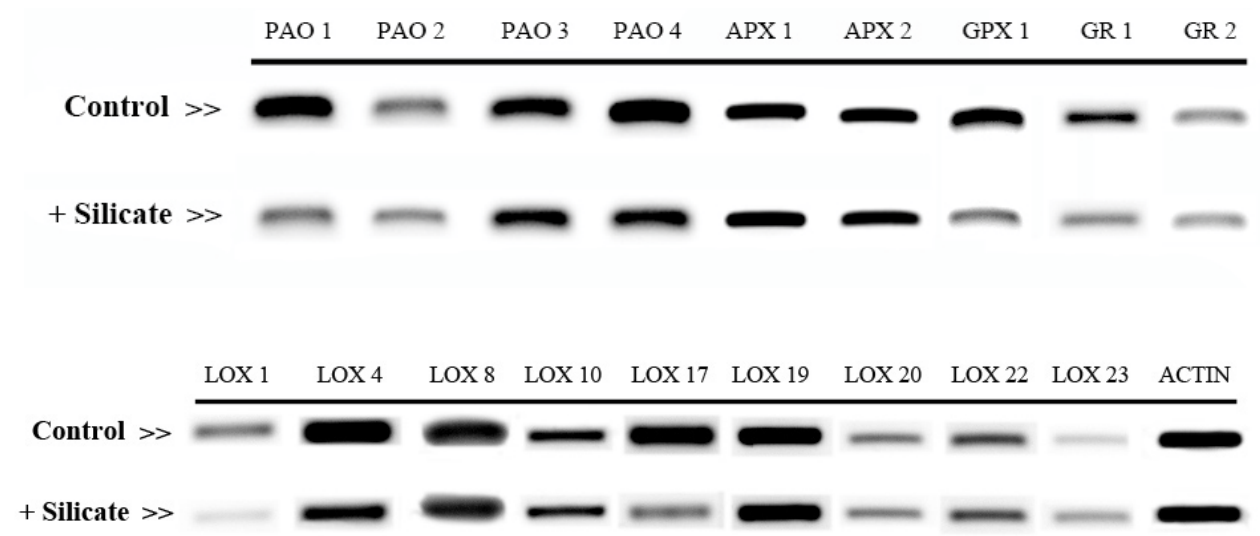

Figure 5. Semi quantitative RT-PCR results of selected genes affected by Si treatment from cucumber leaf samples in comparison with control plants.

In order to investigate the regulation of pro-oxidant systems, gene coding for PAO and LOX enzymes were selected as described above and their expression level was studied upon Si supplementation fertigation. Despite vigorous database searches and evidence for 
DAO activity in cucumber (see above), we could not identify putative $D A O$ genes in the cucumber genome.

In order to validate the semi-quantitative RT-PCR results, several representative genes were subjected to RT-qPCR analysis. RT-qPCR data for the PAO 1, 2 and $L O X$ 4, 7, 22 genes fully confirmed the results obtained by the RT-PCR method (Figure 6).
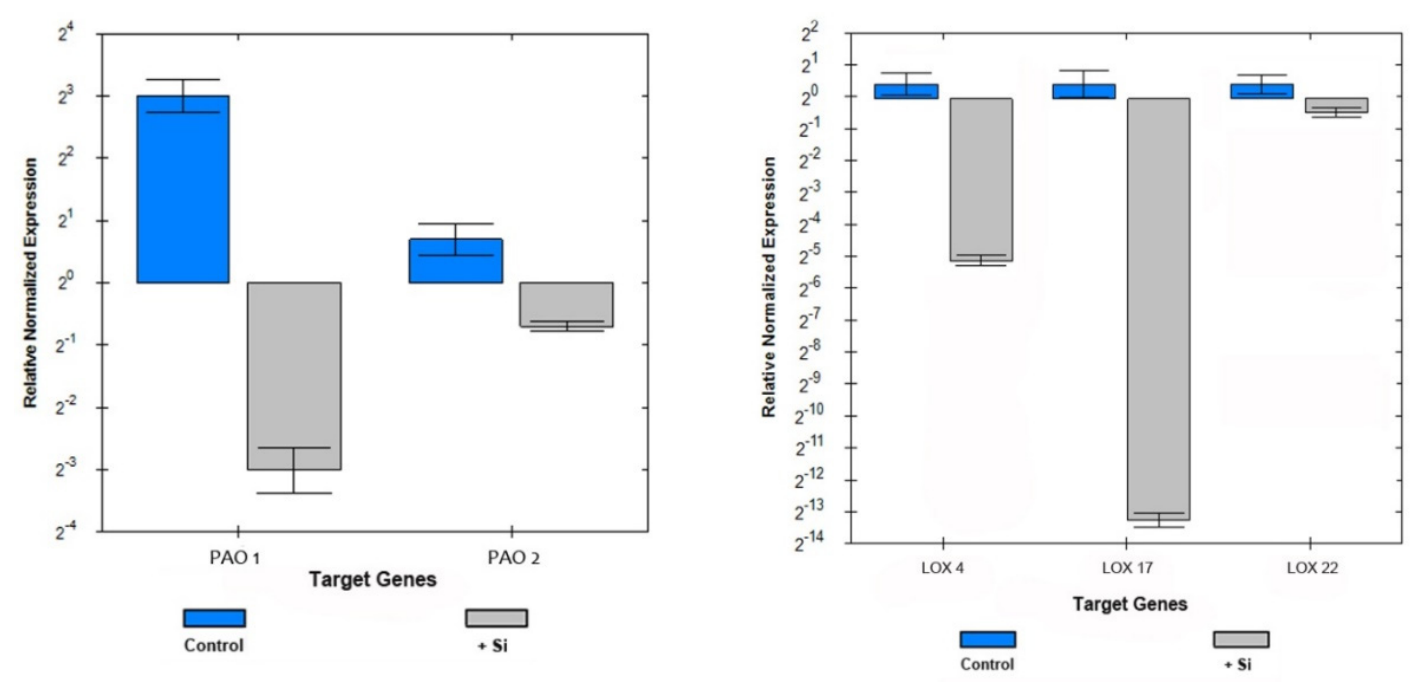

Figure 6. RT-qPCR data for transcript abundance of the PAO1, 2 and $L O X$ 4, 17, 22 genes in control and silicon-treated leaf samples.

\section{Discussion}

Silicon ( $\mathrm{Si}$ ) is an element with potential benefits and variable accumulation rate in different plant species $[3,16]$. Cucumber is a moderate accumulator of $\mathrm{Si}$, which has already been used as a dicot model system for Si effects [17]. A well-known aspect of alleviating environmental stresses by $\mathrm{Si}$ is the decrease in ROS level, which has been attributed so far to the increased expression and activity of antioxidant enzymes. This has been shown in various experimental systems, including salt-stressed cucumber $[4,5,9]$. In an attempt to further elaborate mechanisms of silicate action, we aimed to elucidate whether prooxidative systems, especially amine oxidases and lipoxygenases, might be affected by $\mathrm{Si}$ exposure.

In order to keep potentially interfering physiological processes at the minimum, we did not apply stress treatments to the experimental plants. Instead, we studied nonstressed plants of the F1 cultivar hybrid 'Joker', which displayed low-level hydrogen peroxide accumulation and lipid peroxidation in the leaves under the applied in vitro growth conditions. $\mathrm{H}_{2} \mathrm{O}_{2}$ content was measured directly, while lipid peroxidation was assessed by determining specific metabolites and also by bio-photon imaging, which is a powerful, non-destructive method serving this purpose [18]. Upon silicon provision, biophoton imaging, $\mathrm{H}_{2} \mathrm{O}_{2}$ content, and direct measurement of lipid peroxidation demonstrated that $\mathrm{Si}$ treatment alleviated oxidative stress (Figures $3-5$ respectively). For an explanation of the mild oxidative stress observed in the plants, we note that 'Joker' is a hybrid bred for and usually grown in open field cultivation. Its root system is adapted for growth in open soil rather than in the confined space available in the pots. This situation probably represents physical stress [19], potentially provoking a systemic response [20] and may therefore be responsible for the mild oxidative burden in shoots of otherwise non-stressed 'Joker' plants. Seedlings may have also experienced slightly hypoxic conditions when growing in Rockwool blocks saturated with nutrient solution and by the partial submergence of their root system, creating similar physiological consequences [21].

In order to shed light on the origin of the observed redox protective effect, we studied the expression of genes for antioxidant enzymes in control and treated plants. The expression of the selected genes is indicative of the ascorbate-glutathion cycle (APX and 
GR) and of the glutathione peroxidase cycle (GPX and GR). Despite expectations, we found a coordinated downregulation of gene coding for key components of antioxidant cycles upon Si treatment. This was in contrast with results described earlier in salt-stressed cucumber [9], where it was presumed that the observed changes in redox homeostasis may be caused by other metabolic alterations. We went on to investigate the potential involvement of pro-oxidant systems' regulation in the observed effects of $\mathrm{Si}$ on the redox status. Amine oxidases (polyamine oxidases (PAOs), diamine oxidases (DAOs)) and lipoxygenases (LOXs) are well-known for their production of $\mathrm{H}_{2} \mathrm{O}_{2}$ and peroxygenated lipid species, respectively [13]. Association between polyamines and the role of $\mathrm{Si}$ in salt stress protection has been proposed [10] with the silicon-mediated downregulation of PAO or DAO activities. During our studies, however, a profound inhibitory effect of Si was also found on pro-oxidant PAO and DAO enzyme activities as well as on PAO gene expression in the cultivar hybrid 'Joker' subjected to a different type of stress. In silicon-treated plants, the total PAO and DAO activities declined, and so did the transcript level of several PAO and $L O X$ genes. We could not identify candidate $D A O$ genes in the genome of cucumber, although the corresponding enzyme activity was clearly present. A coordinated downregulation of $L O X$ genes was also found in another cucumber hybrid in response to $\mathrm{Si}$ treatment, under different growth conditions [22]. This confirms this regulatory step as a likely common feature of $\mathrm{Si}$ action in cucumber. Association of Si with the cell wall and its effects on apoplast-related processes have been put forward [6,23]. Based on this association, extracellular space is an obvious compartment to look for potential mediators of silicate effects on redox balance. Polyamine and diamine oxidases are among known sources of apoplastic ROS [11].

According to the results presented here, Si treatment downregulated PAO and DAO activities and decreased $\mathrm{H}_{2} \mathrm{O}_{2}$ content with no associated growth promotion of the seedlings (Figure 1B). Similar to our results, silicon treatment also downregulated PAO activity in $\mathrm{K}$-deficient sorghum, resulting in decreased putrescin and $\mathrm{H}_{2} \mathrm{O}_{2}$ levels and the alleviation of stress symptoms [24]. Mutations of $P A O$ genes in the model plant Arabidopsis also caused the reduction of ROS levels [25].

The presented results suggest a negative impact of $\mathrm{Si}$ on enzymatic systems producing reactive oxygen species. Whether or not the downregulation of these enzyme activities affects transcription is not yet clear and deserves further attention. One possible scenario is that $\mathrm{Si}$ acts indirectly on gene expression by interfering with metabolism and/or the cellular transport of polyamines, which may well lead to profound and diverse effects on gene regulation [26]. Further on, the interference of $\mathrm{Si}$ with polyamine metabolism and transport may also be indirect. Si might modulate apoplastic processes associated with systemic stress responses similar to what was found in a case of a biotic interaction in tomato [27].

Apart from these uncertainties, our data definitely prove that silicon can modulate pro-oxidant enzymatic processes, uncovering the large regulatory potential of this effect. We have to note, however, that the actual effects of $\mathrm{Si}$ on diverse physiological and signaling processes are likely to be variable depending on the species, genotypes, and conditions/treatments.

\section{Materials and Methods}

\subsection{Plant Growth and Silicate Treatment}

The open field-grown cucumber F1 cultivar hybrid 'Joker' was considered and used in this research. Seeds were obtained from Royal Sluis Magrovet (Hungary), submerged in $100 \mathrm{~mL}$ of distilled water for $24 \mathrm{~h}$ at $25^{\circ} \mathrm{C}$ to imbibe. Four seeds were planted in $7.5 \times 7.5 \times 6.5 \mathrm{~cm}^{3}$ rockwool cubes and inserted into $20 \mathrm{~cm}$ diameter pots containing $200 \mathrm{~g}$ of perlite and grown at $26 \pm 1^{\circ} \mathrm{C}$ in a photoperiod of $16 \mathrm{~h}$ with a photosynthetic photon flux density of $150 \mu \mathrm{mol} \mathrm{m}{ }^{-2} \mathrm{~s}^{-1}$ at culture level (provided by cool-white fluorescent lamps) and at $55-60 \%$ of relative humidity. The fertigation solution contained $2 \mathrm{mM}$ potassium dihydrogen phosphate, $0.5 \mathrm{mM}$ magnesium sulfate heptahydrate, $1.5 \mathrm{mM}$ calcium sulfate 
dihydrate, $0.05 \mathrm{mM}$ ferric sodium ethylenediaminetetraacetate, $0.5 \mathrm{mM}$ morpholineethanesulfonic acid, $4 \mathrm{mM}$ potassium nitrate, $0.572 \mathrm{mg} . \mathrm{L}^{-1}$ boric acid, $0.362 \mathrm{mg} . \mathrm{L}^{-1}$ manganese chloride tetrahydrate, $0.044 \mathrm{mg} . \mathrm{L}^{-1}$ zinc sulfate, $0.016 \mathrm{mg} . \mathrm{L}^{-1}$ copper sulfate, $0.004 \mathrm{mg} . \mathrm{L}^{-1}$ molybdenum trioxide. Silicate treatment was applied by fortification of the above solution with sodium silicate $(1.67 \mathrm{mM})$. Control and Si supplemented fertigation $(250 \mathrm{~mL}$ per pot) were applied every other day after expansion of cotyledons and the emergence of the first true leaves. Pots were partially $(\sim 2 \mathrm{~cm})$ submerged in drained fertigation solution, with the $\mathrm{pH}$ adjusted daily to 6.0. Treatments continued for 21 days when fully expanded leaves were selected from each treatment. Growth rate was monitored by measuring the fresh weight of the shoot before processing leaf samples. Samples were taken to be used immediately or collected deep frozen in liquid nitrogen and stored at $-80^{\circ} \mathrm{C}$ for further molecular analysis. Two intact plants in each pot were analyzed with bio-photon emission imaging. All subsequent experiments were performed at least twice on different biological materials.

\subsection{Ultra-Weak Bio-Photon Emission}

Leaves of cucumber plants grown under $\mathrm{Si}$ treatments were subjected to ultra-weak photon emission imaging. Intact leaves of approximately the same size were detached from the plants and instantly placed in the chamber of NightShade LB 985 Plant Imaging System (Berthold Technologies, Bad Wildbad, Germany). Luminescence emissions from the leaves of control and Si-treated plants were imaged using thermoelectrically cooled $\left(-70^{\circ} \mathrm{C}\right) \mathrm{CCD}$ camera (NightOWLcam, Berthold Technologies) mounted on a dark, light-tight chamber. A back-lit, midband-coated full frame chip with a spectral range of 350-1050 nm (quantum efficiency: $90 \%$ at $620 \mathrm{~nm}$ ) was employed for photon detection and XY-imaging. The final resolution of $512 \times 512$ pixels and $26 \times 26 \mu \mathrm{m}^{2}$ pixel size (slow scan mode) were obtained by setting the variable binning to $2 \times 2$ and the exposure time to $60 \mathrm{~s}$. IndiGo software (V. 2.0.5.0, Berthold Technologies, Germany) was used for image analysis. The presented images are selected from a series of photos taken and represent the highest detected signal intensity level in each treatment.

\subsection{Measurement of $\mathrm{Si}_{2} \mathrm{H}_{2} \mathrm{O}_{2}$, and Lipid Hydroperoxide Content, DAB Staining}

Surface impurities were washed off the leaves with tap water after harvest. Si content was determined in leaf samples, which were dried at $37^{\circ} \mathrm{C}$ for 2 days to obtain $5.0 \mathrm{~g}$ of the dried material from both Si-treated and control plants. Dry matter was ground to -200 mesh using a laboratory-type disc mill and $1.0 \mathrm{~g}$ of homogenized powder samples were incinerated in crucibles at $500^{\circ} \mathrm{C}$ for $1 \mathrm{~h}$ to remove any organic matter. After cooling, $10 \mathrm{~mL}$ of $1 \mathrm{M} \mathrm{HCl}$ solution was added to the crucible, the mixture was filtered, and the crucible was washed twice with $10 \mathrm{~mL}$ of distilled water. The filtrate volume was then increased to $50 \mathrm{~mL}$ with distilled water. Optical emission spectroscopy of atoms excited by inductively coupled plasma (ICP-OES Ultima 2, HORIBA Jobin Yvon, Longjumeau, France) was employed at $251.921 \mathrm{~nm}$ and $252.851 \mathrm{~nm}$ wavelengths, results were expressed as mg.g ${ }^{-1}$ DW. $\mathrm{H}_{2} \mathrm{O}_{2}$, and lipid hydroperoxide content of the leaves were measured at $560 \mathrm{~nm}$ in the spectrophotometer, based on colorimetric reaction, as previously described by Kellós et al. [28]. Briefly, $200 \mathrm{mg}$ of plant leaf samples were homogenized in $1 \mathrm{~mL}$ of $10 \%$ phosphoric acid. The supernatant was used for the determination of $\mathrm{H}_{2} \mathrm{O}_{2}$ and lipid hydroperoxides. $50 \mu \mathrm{L}$ of the sample extract was mixed with a $950 \mu \mathrm{L}$ mixture containing $100 \mu \mathrm{M}$ Xylenol Orange, $250 \mu \mathrm{M}$ ammonium ferrous sulphate, $100 \mu \mathrm{M}$ sorbitol, and $25 \mu \mathrm{M}$ sulfuric acid for $\mathrm{H}_{2} \mathrm{O}_{2}$ analysis or $100 \mu \mathrm{M}$ Xylenol Orange, $250 \mu \mathrm{M}$ ammonium ferrous sulphate, $90 \%$ methanol, $4 \mathrm{mM}$ butylated hydroxytoluene, and $25 \mu \mathrm{M}$ sulfuric acid for lipid hydroperoxide analysis. For both compounds $\mathrm{H}_{2} \mathrm{O}_{2}$ was used for calibration. In situ visualization of hydrogen peroxide level in leaves with $\mathrm{DAB}$ staining was carried out as described by Liu and Friesen [29]. Intact leaves were vacuum infiltrated for $10 \mathrm{~min}$ in a solution containing $1 \mathrm{mg} . \mathrm{mL}^{-1}$ 3,3-diaminobenzidine (DAB), $0.05 \%$ Tween 20 , and $10 \mathrm{mM}$ $\mathrm{Na}_{2} \mathrm{HPO}_{4}$ dissolved in water, the $\mathrm{pH}$ of which was previously adjusted to 3.6 with $0.2 \mathrm{M}$ 
$\mathrm{HCl}$. After $18 \mathrm{~h}$ of incubation leaves were bleached in ethanol/acetic acid/glycerol (3/1/1, $v / v / v$ ) solution in a boiling water bath for $10 \mathrm{~min}$ before imaging.

\subsection{Amine Oxidases and Ascorbate Peroxidase Enzyme Activities}

The activity of diamine oxidase (DAO, EC1.4.3.6.) and polyamine oxidase (PAO, EC 1.5.3.3.) enzymes was estimated by the method of Takács et al. [30], with minor modifications. A total of $300 \mathrm{mg}$ of excised leaf tissues were homogenized in $0.9 \mathrm{~mL}$ of ice-cold extraction buffer containing $0.2 \mathrm{M}$ Tris- $\mathrm{HCl}$ ( $\mathrm{pH} 8.0$ ), $10 \%$ glycerol, $0.25 \%$ Triton $\mathrm{X}-100 ; 0.5 \mathrm{mM}$ phenylmethanesulfonyl fluoride (PMSF). The homogenate was left on ice for $20 \mathrm{~min}$, then centrifuged $\left(10 \mathrm{~min}, 12,000 \mathrm{rpm}, 4^{\circ} \mathrm{C}\right)$ and the supernatant was decanted. The reaction mixture (total volume of $830 \mu \mathrm{L}$ ) contained $0.15 \mathrm{~mL}$ of crude enzyme extract, $0.6 \mathrm{~mL}$ of $100 \mathrm{mM}$ sodium phosphate buffer ( $\mathrm{pH}$ 6.6), $7.5 \mu \mathrm{L}$ of $1 \mathrm{M}$ Putrescine for DAO, and $7.5 \mu \mathrm{L}$ of $1 \mathrm{M}$ Spermidine for PAO measurements. The reaction was carried out at $37^{\circ} \mathrm{C}$ for $1.5 \mathrm{~h}$ and was stopped with $50 \mu \mathrm{L}$ of $20 \%$ trichloroacetic acid (TCA). Subsequently, $22.5 \mu \mathrm{L}$ of $10 \mathrm{mg} \cdot \mathrm{mL}^{-1}$ 2-aminobenzaldehyde was added to the mixture, incubated on ice for $30 \mathrm{~min}$, and centrifuged at $10,000 \times \mathrm{g}$ for $10 \mathrm{~min}$ at $4{ }^{\circ} \mathrm{C}$. Enzyme activity was measured at $430 \mathrm{~nm}$ in the spectrophotometer and expressed in nmol $\Delta 1$-pyrroline $\mathrm{min}^{-1} \cdot \mathrm{g}^{-1} \mathrm{FW}$ using an extinction coefficient of $1.86 \times 103 \mathrm{~mol}-1 . \mathrm{cm}-1$. Ascorbate peroxidase (APX, EC 1.11.1.1) activity was assayed according to Chandrakar et al. [31] by monitoring the rate of ascorbate oxidation at $290 \mathrm{~nm}$. Leaf samples $(200 \mathrm{mg}$ ) were homogenized in a $600 \mu \mathrm{L}$ of extraction buffer (100 mM potassium phosphate buffer, $\mathrm{pH} 7.0$, and $0.1 \mathrm{mM}$ EDTA). The homogenate was centrifuged at 13,000 $\mathrm{rpm}$ for $15 \mathrm{~min}$. One $\mathrm{mL}$ reaction mixture comprised of $50 \mathrm{mM}$ phosphate buffer ( $\mathrm{pH}$ 6.0), $0.1 \mu \mathrm{M}$ EDTA, $0.5 \mathrm{mM}$ ascorbate, $1.0 \mathrm{mM} \mathrm{H}_{2} \mathrm{O}_{2}$, and $50 \mu \mathrm{L}$ enzyme extract. Enzyme activity was calculated following the extinction coefficient of $0.0028 \mathrm{M}^{-1} \cdot \mathrm{cm}^{-1}$ and expressed as $\mu \mathrm{kat} . \mathrm{g}^{-1} \mathrm{FW}$.

\subsection{RNA Isolation, cDNA Preparation, RT-PCR, and RT-qPCR}

Total RNA was extracted from deep frozen leaf samples (collected from four leaves of the same size and position, from four different plants of different pots) of control and Si-treated plants by grinding in liquid $\mathrm{N}_{2}$ using sterile mortar and pestles. A modified CTAB-based protocol [32] was used to obtain high quality RNA as visualized on an EcoSafe-stained 1\% agarose gel. RNA concentration was measured in a NanoDrop 1000 spectrophotometer and equalized to $10 \mu \mathrm{g}$ per $100 \mu \mathrm{L}$ in DNase I (Thermo Scientific) reaction mix. DNase-treated RNA integrity was ensured on agarose gel before reverse transcription. Five $\mu \mathrm{g}$ of total RNA was used for first-strand cDNA synthesis using the Maxima Reverse Transcriptase kit (Thermo Scientific) with oligo(dT)20 primers, according to the manufacturer's protocol. Primers of selected redox-related genes and a control actin gene (Table S1.) were tested for PCR amplification with Dream Taq DNA polymerase (Thermo Scientific). Amplification was achieved in a Master Cycler instrument (Eppendorf AG, Hamburg, Germany) with $3 \mathrm{~min}$ at $95{ }^{\circ} \mathrm{C}$ and 26 cycles of $30 \mathrm{~s}: 95^{\circ} \mathrm{C}, 60 \mathrm{~s}: 58{ }^{\circ} \mathrm{C}$, $30 \mathrm{~s}: 72^{\circ} \mathrm{C}$, and a final extension for $7 \mathrm{~min}$ at $72{ }^{\circ} \mathrm{C}$. Amplified genomic DNA and cDNA fragments were visualized on ethidium bromide-stained agarose gels. RT-qPCR was performed in a CFX 96 Real-Time PCR System (Bio-Rad, USA) using the SsoAdvanced Universal Inhibitor-Tolerant SYBR ${ }^{\circledR}$ Green Supermix (Bio-Rad) for fluorescence detection in a 96-well optical plate. The total volume of each qPCR reaction was $10 \mu \mathrm{L}$, containing $1 \mu \mathrm{L}$ of $\mathrm{cDNA}, 4 \mu \mathrm{L}$ of super mix, $0.5 \mu \mathrm{L}(100 \mathrm{uM})$ of forward and reverse primers, and $4 \mu \mathrm{L}$ of PCR-grade water. Amplification was initiated with polymerase activation and DNA denaturation at $95{ }^{\circ} \mathrm{C}$ for $30 \mathrm{~s}$, followed by 40 cycles of denaturation at $95^{\circ} \mathrm{C}$ for $10 \mathrm{~s}$, annealing and extension at $60{ }^{\circ} \mathrm{C}$ for $30 \mathrm{~s}$. A melting curve analysis $\left(65-95^{\circ} \mathrm{C}\right)$ at the end of the run confirmed the specificity of the PCR products. Efficiency of PCR and stability of the endogenous standard gene (Actin-3 gene; DQ115883) were evaluated and sufficiently confirmed as described in Oszlányi et al. [33]. Fold changes of the examined gene expression were estimated by the $2^{-\Delta \Delta \mathrm{Ct}}$ method [34]. 


\subsection{Statistical Analysis}

Data obtained from measurements were statistically analyzed with the statistical software IBM SPSS (v25) (IBM Corp, Armonk, NY, USA). Results are shown as mean values with standard deviations among three biological replicates. The normal distribution of residuals was proved by Shapiro-Wilk's test $(p>0.05)$ and the homogeneity of variances was checked by Levene's test $(p>\alpha)(\alpha=0.05)$. The differences among the mean values were evaluated by one-way ANOVA and considered significant at $p<0.05$. The presented diagrams were produced in MS Excel.

Supplementary Materials: The following are available online at https://www.mdpi.com/article/ 10.3390/plants10061248/s1, Table S1: Target genes, oligonucleotide primers, and expected product sizes in RT-PCRs and RT-qPCRs.

Author Contributions: Conceptualization, I.P.; methodology, I.P., A.S. and I.M.; software, Z.P.; validation, I.P., A.S. and I.M.; investigation, A.S., I.M., Z.P., M.O., E.K.-B., M.G. and O.B.-E.; data curation, A.S. and I.M.; writing-original draft preparation, I.P., A.S. and I.M.; writing-review and editing, I.P., I.M. and A.S.; visualization, A.S and I.M. All authors have read and agreed to the published version of the manuscript.

Funding: This research was funded by the National Research, Development and Innovation Office, Hungary (TKP2020-IKA-12). The work/publication is supported by the GINOP-2.2.1-15-2016-00021 and EFOP-3.6.3-VEKOP-16-2017-00008 project. The project is also co-financed by the European Union and the European Regional Development Fund, and the European Union and the European Social Fund.

Conflicts of Interest: The authors declare no conflict of interest.

\section{References}

1. Luyckx, M.; Hausman, J.F.; Lutts, S.; Guerriero, G. Silicon and plants: Current knowledge and technological perspectives. Front. Plant Sci. 2017, 8, 1-8. [CrossRef]

2. Yan, G.; Nikolic, M.; Ye, M.; Xiao, Z.; Liang, Y. Silicon acquisition and accumulation in plant and its significance for agriculture. J. Integr. Agric. 2018, 17, 2138-2150. [CrossRef]

3. Kim, Y.H.; Khan, A.L.; Lee, I.J. Silicon: A duo synergy for regulating crop growth and hormonal signaling under abiotic stress conditions. Crit. Rev. Biotechnol. 2015, 36, 1099-1109. [CrossRef]

4. Zhu, Y.; Gong, H. Beneficial effects of silicon on salt and drought tolerance in plants. Agron. Sustain. Dev. 2014, 34, 455-472. [CrossRef]

5. Rizwan, M.; Ali, S.; Ibrahim, M.; Farid, M.; Adrees, M.; Bharwana, S.A.; Zia-ur-Rehman, M.; Qayyum, M.F.; Abbas, F. Mechanisms of silicon-mediated alleviation of drought and salt stress in plants: A review. Environ. Sci. Pollut. Res. 2015, 22, 15416-15431. [CrossRef] [PubMed]

6. Guerriero, G.; Hausman, J.F.; Legay, S. Silicon and the plant extracellular matrix. Front. Plant Sci. 2016, 7, 463. [CrossRef] [PubMed]

7. Shetty, R.; Fretté, X.; Jensen, B.; Shetty, N.P.; Jensen, J.D.; Jørgensen, H.J.L.; Newman, M.A.; Christensen, L.P. Silicon-induced changes in antifungal phenolic acids, flavonoids, and key phenylpropanoid pathway genes during the interaction between miniature roses and the biotrophic pathogen Podosphaera pannosa. Plant Physiol. 2011, 157, 2194-2205. [CrossRef]

8. Coskun, D.; Deshmukh, R.; Sonah, H.; Menzies, J.G.; Reynolds, O.; Ma, J.F.; Kronzucker, H.J.; Bélanger, R.R. The controversies of silicon's role in plant biology. New Phytol. 2019, 221, 67-85. [CrossRef] [PubMed]

9. Zhu, Z.; Wei, G.; Li, J.; Qian, Q.; Yu, J. Silicon alleviates salt stress and increases antioxidant enzymes activity in leaves of salt-stressed cucumber (Cucumis satious L.). Plant Sci. 2004, 167, 527-533. [CrossRef]

10. Yin, J.; Jia, J.; Lian, Z.; Hu, Y.; Guo, J.; Huo, H.; Zhu, Y.; Gong, H. Silicon enhances the salt tolerance of cucumber through increasing polyamine accumulation and decreasing oxidative damage. Ecotoxicol. Environ. Saf. 2019, 169, 8-17. [CrossRef]

11. Podgórska, A.; Burian, M.; Szal, B. Extra-cellular but extra-ordinarily important for cells: Apoplastic reactive oxygen species metabolism. Front. Plant Sci. 2017, 8, 1-20. [CrossRef]

12. Yu, Z.; Jia, D.; Liu, T. Polyamine oxidases play various roles in plant development and abiotic stress tolerance. Plants 2019, 6, 184. [CrossRef]

13. Viswanath, K.K.; Varakumar, P.; Pamuru, R.R.; Basha, S.J;; Mehta, S.; Rao, A.D. Plant lipoxygenases and their role in plant physiology. J. Plant Biol. 2020, 63, 83-95. [CrossRef]

14. Zhou, Y.; Hu, L.; Ye, S.; Jiang, L.; Liu, S. Genome-wide identification of glutathione peroxidase (GPX) gene family and their response to abiotic stress in cucumber. 3 Biotech 2018, 8, 1-11. [CrossRef] 
15. Yang, X.Y.; Jiang, W.J.; Yu, H.J. The expression profiling of the lipoxygenase (LOX) family genes during fruit development, abiotic stress and hormonal treatments in cucumber (Cucumis sativus L.). Int. J. Mol. Sci. 2012, 13, 2481-2500. [CrossRef]

16. Coskun, D.; Britto, D.T.; Huynh, W.Q.; Kronzucker, H.J. The role of silicon in higher plants under salinity and drought stress. Front. Plant Sci. 2016, 7, 1072. [CrossRef] [PubMed]

17. Zhu, Y.; Yin, J.; Liang, Y.; Liu, J.; Jia, J.; Huo, H.; Wu, Z.; Yang, R.; Gong, H. Transcriptomic dynamics provide an insight into the mechanism for silicon-mediated alleviation of salt stress in cucumber plants. Ecotoxicol. Environ. Saf. 2019, 174, $245-254$. [CrossRef] [PubMed]

18. Birtic, S.; Ksas, B.; Genty, B.; Mueller, M.J.; Triantaphylidès, C.; Havaux, M. Using spontaneous photon emission to image lipid oxidation patterns in plant tissues. Plant J. 2011, 67, 1103-1115. [CrossRef]

19. Raviv, M.; Lieth, J.H.; Bar-Tal, A. (Eds.) Growing plants in soilless culture: Operational conclusions. In Soilless Culture, 2nd ed.; Academic Press: Cambridge, MA, USA, 2019; pp. 637-669.

20. Fichman, Y.; Mittler, R. Rapid systemic signaling during abiotic and biotic stresses: Is the ROS wave master of all trades? Plant J. 2020, 102, 887-896. [CrossRef]

21. Morard, P.; Silvestre, J. Plant injury due to oxygen deficiency in the root environment of soilless culture: A review. Plant Soil. 1996, 184, 243-254. [CrossRef]

22. Bat-Erdene, O.; Szegő, A.; Gyöngyik, M.; Mirmazloum, I.; Papp, I. Long term silicon exposure coordinately downregulates lipoxygenase genes, decreases reactive oxygen species level and promotes growth of cucumber plants in a semi-hydroponic cultivation system. Russ. J. Plant Physiol. 2021, accepted, in press. [CrossRef]

23. Law, C.; Exley, C. New insight into silica deposition in horsetail (Equisetum arvense). BMC Plant Biol. 2011, 11, 112. [CrossRef]

24. Chen, D.; Cao, B.; Qi, L.; Yin, L.; Wang, S.; Deng, X. Silicon-moderated K-deficiency-induced leaf chlorosis by decreasing putrescine accumulation in sorghum. Ann. Bot. 2016, 118, 305-315. [CrossRef]

25. Kim, D.W.; Watanabe, K.; Murayama, C.; Izawa, S.; Niitsu, M.; Michael, A.J.; Berberich, T.; Kusano, T. Polyamine oxidase 5 regulates arabidopsis growth through thermospermine oxidase activity. Plant Physiol. 2014, 165, 1575-1590. [CrossRef]

26. Chen, D.; Shao, Q.; Yin, L.; Younis, A.; Zheng, B. Polyamine function in plants: Metabolism, regulation on development, and roles in abiotic stress responses. Front. Plant Sci. 2019, 9, 1945. [CrossRef]

27. Kurabachew, H.; Wydra, K. Induction of systemic resistance and defense-related enzymes after elicitation of resistance by rhizobacteria and silicon application against Ralstonia solanacearum in tomato (Solanum lycopersicum). Crop Prot. 2014, 57, 1-7. [CrossRef]

28. Kellős, T.; Tímár, I.; Szilágyi, V.; Szalai, G.; Galiba, G.; Kocsy, G. Stress hormones and abiotic stresses have different effects on antioxidants in maize lines with different sensitivity. Plant Biol. 2008, 10, 563-572. [CrossRef] [PubMed]

29. Liu, Z.; Friesen, T. DAB staining and visualization of hydrogen peroxide in wheat leaves. Bio. Protoc. 2012, 2, e309. [CrossRef]

30. Takács, Z.; Poór, P.; Tari, I. Comparison of polyamine metabolism in tomato plants exposed to different concentrations of salicylic acid under light or dark conditions. Plant Physiol. Biochem. 2016, 108, 266-278. [CrossRef]

31. Chandrakar, V.; Dubey, A.; Keshavkant, S. Modulation of antioxidant enzymes by salicylic acid in arsenic exposed Glycine max L. J. Soil Sci. Plant Nutr. 2016, 16, 662-676. [CrossRef]

32. Jaakola, L.; Pirttilä, A.M.; Halonen, M.; Hohtola, A. Isolation of high quality RNA from bilberry (Vaccinium myrtillus L.) fruit. Appl. Biochem. Biotechnol.-Part B Mol. Biotechnol. 2001, 19, 201-203. [CrossRef]

33. Oszlányi, R.; Mirmazloum, I.; Pónya, Z.; Szegő, A.; Jamal, S.; Bat-Erdene, O.; Papp, I. Oxidative stress level and dehydrin gene expression pattern differentiate two contrasting cucumber F1 hybrids under high fertigation treatment. Int. J. Biol. Macromol. 2020, 161, 864-874. [CrossRef] [PubMed]

34. Bookout, A.L.; Mangelsdorf, D.J. Quantitative real-time PCR protocol for analysis of nuclear receptor signaling pathways. Nucl. Recept. Signal. 2003, 1, e012. [CrossRef] [PubMed] 